\author{
Ирина Богинская
}

\title{
Коммуникация миротворческой миссии на востоке Украины
}

\begin{abstract}
Abstrakt
W artykule przeanalizowano konflikt o koncepcję misji pokojowej ONZ na wschodzie Ukrainy między Ukrainą a Federacją Rosyjską. Analiza konfliktu opiera się na krytycznym podejściu do oficjalnych narracji zawierających odniesienia do sił pokojowych ONZ w latach 2015-2021. Stwierdzono, że po raz pierwszy koncepcja misji pokojowej ONZ pojawiła się w ukraińskim dyskursie politycznym zaraz po podpisaniu drugiej części porozumień mińskich (Mińsk-2). W centrum dyskursu międzynarodowego znalazła się ona po tym, jak prezydent Rosji W. Putin zainicjował wniesienie projektu rezolucji do Rady Bezpieczeństwa ONZ. Rosyjskie podejście do misji pokojowej było formułowane w ścisłym związku $\mathrm{z}$ realizacją porozumień mińskich i nie pozwalało na ich interpretację. Zasadniczo podejście Federacji Rosyjskiej („koncepcja defensywna”) i Ukrainy („szeroki mandat") rozwijają i dostosowują koncepcję nowoczesnego utrzymania pokoju do interesów stron konfliktu. Narracje rosyjsko-ukraińskie są podstawą do szczegółowego zrozumienia natury konfliktu i możliwych sposobów jego rozwiązania. Wykorzystanie narzędzi propagandowych w celu promowania wielokierunkowego podejścia do sił pokojowych ONZ przeniosło konflikt na wyższy poziom.

Analiza komunikatów misji pokojowej obejmuje formaty negocjacyjne, na których omawiano tę kwestię. Takimi platformami negocjacyjnymi były: format normandzki, Monachijska Konferencja Bezpieczeństwa, Zgromadzenie Ogólne ONZ, spotkania Surkowa-Volkera itd. Rada Bezpieczeństwa ONZ nie przekształciła się w dodatkowy kanał komunikacji, ponieważ nie udało się skoordynować i połączyć stanowisk Ukrainy i Federacji Rosyjskiej. Próby uzgodnienia misji pokojowej w ramach realizacji porozumień mińskich doprowadziły do impasu negocjacyjnego i wykluczenia tego punktu $\mathrm{z}$ agendy negocjacji międzynarodowych.

Artykuł dotyczy kwestii kształtowania się poparcia społecznego dla scenariusza rozwiązania konfliktu w oparciu o działania ONZ. Zagadnienie to zostało zbadane na podstawie badań opinii publicznej oraz arbitralnie dobranych przykładów, które stanowią bazę dowodową do oceny wpływu społeczeństwa
\end{abstract}


obywatelskiego na podejmowanie decyzji na Ukrainie. Jednocześnie pokazano aspekty humanitarne, które mogłyby potencjalnie wpłynąć na procesy rozwiązywania konfliktu w Donbasie.

Słowa kluczowe: misja pokojowa, komunikacja, Ukraina, Federacja Rosyjska, ONZ, porozumienia mińskie

\section{Постановка проблемы}

Тема миротворческой миссии на востоке Украины, активно обсуждаемая в медиа-пространстве в 2015-2019 гг., оказалась практически вытесненной из общественного и политического дискурса после президентских выборов в Украине. На уровне экспертной оценки миротворческая операция под эгидой ООН до недавно признавалась одним из наиболее перспективных и приоритетных вариантов восстановления мира на Донбассе. Однако при этом экспертное сообщество оценивало возможность организации такой миссии как маловероятную. Заслуживает внимания существенная разница, наблюдаемая между общественными настроениями и мнением экспертного сообщества. Регулярно проводимые в 2015-2019 гг. социологические опросы показывали устойчивую общественную поддержку сценария миротворческой миссии - 59\%. Разница в подходах и восприятиях различных вариантов разрешения конфликта нацеливает на анализ коммуникации, в центре которой находится организация миротворческой миссии на востоке Украины. Поскольку основой урегулирования и восстановления мира является политика (политическое соглашение), анализ коммуникации прежде всего раскрывает цели, интересы, позиции участников в конфликте, их стремление обеспечить за собой контроль над процессами миростроительства. Одновременно политическая коммуникация формирует пространство урегулирования конфликта, в котором присутствуют разные альтернативы и точки зрения, включая общественный запрос на восстановление мира или настроения в пользу продолжения конфликта. При правильной коммуникации конфликт может быть выведен на тот уровень, где он может разрешиться. Другие варианты коммуникации могут относиться лишь к отдельным фрагментам конфликта, не включать всех участников, и таким образом искажать настоящую природу конфликта.

Организация миротворческой миссии представляет собой вариант урегулирования, расширяющий пространство зоны потенциального соглашения в переговорном процессе. Важным представляется рассмотрение вопроса контроля над коммуникацией, который позволяет описывать ее либо как „продолжение конфликта” иными средствами, либо как поиск 
совместного решения проблемы. Официальные нарративы участников коммуникации являются ключом к идентификации сторон конфликта.

Поиск возможных вариантов урегулирования конфликта на востоке Украины не может быть ограничен жесткими рамками Минских соглашений. Гибкий подход к имплементации пунктов соглашений позволил бы учесть важные элементы новой политической реальности, возникшей за несколько лет по обеим сторонам от линии разграничения на Донбассе.

\section{Идея миротворческой миссии на востоке Украины: борьба официальных нарративов}

Коммуникация официальных лиц Украины и РФ в вопросах миротворческой миссии ООН на востоке Украины свидетельствует об отсутствии намерений нормализовать двусторонние отношения и урегулировать конфликт. Даже при том, что российская сторона последовательно отказывается признавать себя стороной конфликта, взаимодействие политиков двух стран в данном вопросе создало еще одно пространство конфликта, выведя его на более высокий уровень. И российская, и украинская сторона по-своему стремились использовать тему „миротворцев ООН” для пропаганды своих подходов, поиска новых каналов коммуникации, которые помогли бы усилить собственную позицию и одновременно ослабить позицию противоположной стороны. Итогом борьбы официальных нарративов можно считать отсутствие пункта о международном миротворческом контингенте в повестке дня переговоров по урегулированию конфликта на востоке Украины; замещение в общественном и политическом дискурсе темы „миротворцев ООН” темой „российских миротворцев”; попытки использовать вопрос о миротворческой миссии на Донбассе в политической борьбе между властью и оппозицией в Украине.

Несмотря на то, что изначально идея организации миротворческой миссии ООН принадлежала украинской стороне, российской дипломатии спустя некоторое время удалось перехватить инициативу и поставить в центр международных переговоров свое видение такой миссии, оформив его в проект резолюции СБ ООН. Как оказалось, стороны предлагали два различных подхода. Российский подход основывался на необходимости строгого выполнения Минских соглашений (Минский протокол от 5 IX 2014 г., Меморандум к Минскому протоколу от 19 IX 2014 г., Комплекс мер по выполнению Минских соглашений от 12 II 2015 г.) - комплекса документов, в которых отсутствовало упоминание о миротворцах. Поэтому в 2015-2016 гг. российские дипломаты вообще отказывались обсуждать идею введения международного миротворческого контингента ООН в зону конфликта. Всего за несколько 
дней до того, как президент РФ В. Путин анонсировал готовность к обсуждению темы на площадке СБ ООН, российские официальные лица делали заявления, направленные на дискредитацию попыток Украины ввести в переговорное пространство урегулирования пункт о миротворцах $\mathrm{OOH}$. Так, во время брифинга 24 VIII 2017 г. директор департамента информации и печати МИД РФ М. Захарова называла инициативы украинских политиков „очевидными попытками в очередной раз замотать процесс реализации „Минска-2” и уклониться от выполнения собственных обязательств”. По мнению постоянного представителя РФ при ООН В. Небензя предложения о миротворческой операции были „рассчитаны на внутреннее потребление и представляют собой маневр украинских властей”2. Неожиданные изменения в переговорной позиции одной из сторон чаще всего оказываются тактическим ходом. Выступая с инициативой по поводу миротворцев, президент РФ одновременно высказал предостережения относительно поставок Украине американского летального оружия. К моменту, когда 5 IX 2017 г. В. Путин поручил российскому МИД внести на рассмотрение СБ ООН проект резолюции о миротворческой миссии на востоке Украины, в Минске уже состоялась предварительная встреча помощника президента РФ В. Суркова и спецпредставителя госдепартамента США по Украине К. Волкера, ставшая импульсом к оформлению нового канала коммуникации.

В целом российские предложения не выходили за рамки концепции „защитной миссии" ООН, которая предусматривала усиление безопасности представителей СММ ОБСЕ в зоне конфликта (первоначально - только на линии разграничения). Одним из ключевых пунктов данных предложений была необходимость установления прямой коммуникации представителей Украины и ОРДЛО. Таким образом, проект резолюции, направленный российскими дипломатами в начале сентября 2017 г. генсеку ООН А. Гутеррешу и председателю СБ ООН Т. Алему, не выходил за рамки ранее заявленной позиции строгого выполнения Минских соглашений³

Что касается украинской стороны, то на официальном уровне идея введения миротворческой миссии ООН на Донбасс впервые была озвучена в марте 2015 г. ${ }^{4}$ Это произошло практически сразу после подписания

Захарова: призывами к вводу миротвориев в Донбасс Киев пьтается уклониться от «Минска-2», https://tass.ru/politika/4503828 (20 VII 2021).

2 Небензя: Киев муссирует тему миротворческой миссии в Донбассе для подрыва «Минска-2», https://tass.ru/politika/4526363?utm_source=twitter.com\&utm_medium=social\&utm_campaign=smm_social_share (21 VII 2021).

3 Донбасс приобщают к Объединенным Нациям. Владимир Путин предложил ввести в регион миротвориев ООН, https://www.kommersant.ru/doc/3403004 (17 VII 2021).

4 Указ Президента України „Про рішення Ради національної безпеки і оборони України від 18 лютого 2015 року „Про звернення до Організації Об’єднаних Націй та Європейського 
„Комплекса мер по выполнению Минских соглашений” (Минск-2)5. Сама идея миротворцев не противоречила духу подписанных в Минске документов: восстановление территориальной целостности Украины. Однако украинские политики не уточняли важных деталей, связанных с ее мандатом, территорией развертывания, численностью и т.д. Было понятно, что в будущем они хотели бы избежать ситуации потери контроля над мирными процессами и рассчитывали в этом на поддержку западных партнеров. Предполагалось, что миссии следует попытаться использовать опыт Хорватии, в частности Временной администрации ООН в Восточной Славонии (1996-1998 гг.) 6 . Прилагались конкретные планы относительно этапности развертывания международного миротворческого контингента (например, предложенный министром внутренних дел Украины А. Аваковым план „шаг за шагом”) 7 . С осени 2017 г., когда в центре коммуникации оказалась миротворческая инициатива президента РФ В. Путина, украинские нарративы стали более критичными. Содержание заявлений, сделанных официальными лицами Украины, позволяют уточнить видение Киевом урегулирования конфликта на Донбассе и той роли, которая отводилась в нем миротворцам ООН. На Мюнхенской конференции по безопасности в феврале 2018 г. президент Украины П. Порошенко высказался по данному вопросу достаточно конкретно: миротворческая миссия $\mathrm{OOH}$ необходима для выполнения компонента безопасности, предусмотренного Минскими соглашениями. Он возражал против ограниченных полномочий миссии („миротворцы не должны быть эскорт-сервисом вдоль линии разграничения"), высказывался за присутствие миротворцев на неконтролируемом участке российско-украинской границы, их право разоружать незаконные вооруженные формирования и контролировать вывод иностранных войск из ОРДЛО․․ Основной особенностью украинского подхода является широкий мандат миссии ООН, который предусматривает обеспечение зоны безопасности на всей территории ОРДЛО,

Союзу стосовно розгортання на території України міжнародної операції з підтримання миру та безпеки" №116 від 2 березня 2015p., https://www.president.gov.ua/documents/1162015-18568 (20 VI 2021).

5 Повний текст документів, ухвалених на переговорах в Мінську, https://tyzhden.ua/Politics/129751 (22 VII 2021).

6 Croatian peacekeeping model best for Donbas - Ukraine's ministry for occupied areas, https://www.unian.info/politics/10309443-croatian-peacekeeping-modelbest-for-donbasukraine-s-ministry-for-occupied-areas.htm (13 VI 2021).

Арсен Аваков: У меня есть план. Условно, взять сначала отдельно Горловку, https://www. pravda.com.ua/articles/2018/04/16/7177768/ (3 VIII 2021).

8 Порошенко: Миротвориь ООН не должны быть эскорт-сервисом вдоль линии разграничения, https://gordonua.com/news/war/poroshenko-mirotvorcy-oon-ne-dolzhny-byt-eskort-servisom-vdol-linii-razgranicheniya-232349.html (3 VII 2021). 
создание условий для проведения выборов (временная международная администрация) 9 .

Российские политики несколько раз называли такой подход „оккупацией” Донбасса - термином, который свидетельствует о его неприемлемости для Москвы. Они не приняли идею учреждения военно-гражданской администрации $\mathrm{OOH}$, поскольку увидели в ней инструмент ликвидации политических структур самопровозглашенных республик на слишком раннем этапе урегулирования ${ }^{10}$. Так, министр иностранных дел РФ С. Лавров называл неприемлемыми попытки „превратить (миссию) в некую военно-политическую комендатуру, которая возьмет всю территорию самопровозглашенных республик... и сама уже будет решать, кого избирать и как избирать" ${ }^{11}$. Дипломатический торг и споры вокруг миротворцев указывали на существующую разницу в трактовках миротворчества и политизацию этого инструмента урегулирования конфликтов. Не случайно, сравнивая два подхода к миротворческой миссии на Донбассе, один из участников переговоров, министр иностранных дел Украины П. Климкин, заметил, что между представлениями Москвы и Киева о мандате „голубых касок” „лежат миры"12.

Чтобы избежать двусмысленности и манипуляций по поводу мандата миротворческой миссии, которые неизбежно последовали ввиду разного видения и понимания роли миротворцев в урегулировании конфликта на востоке Украины, заместитель министра иностранных дел Украины С. Кислица даже предложил отказаться от слова „миротворчество” (peace-making) в украинском языке. По его мнению, в 1990-х гг. РФ замаскировала под „миротворчество” гибридную оккупацию Приднестровья, Абхазии и Южной Осетии ${ }^{13}$.

После нескольких безуспешных попыток сблизить позиции сторон, предпринятых в формате Сурков-Волкер, российская дипломатия вернулась на первоначально заявленные позиции. Об этом свидетельствует возврат в российском официальном политическом дискурсе к дискредитации идеи миротворческой миссии ООН как инструмента урегулирования. Так,

9 Клімкін: Росія пропонує «тотально фейкову місію» ООН на Донбасі, https://www. ukrinform.ua/rubric-polytics/2478639-klimkin-rosia-proponue-totalno-fejkovu-misiu-oonna-donbasi.html (3 VII 2021).

10 О. Игнатов, Не рвать и не выполнять. Есть ли шансы у Минска-2 после четырех лет переговоров, https://carnegie.ru/commentary/78336 (3 VII 2021).

11 Так не пойдет. Лавров заблокировал идеи США по миротворческой миссии на Донбассе, https://vesti.lv/statja/v-mire/2018/06/12/tak-ne-poydet-lavrov-zabrakoval-ideyu-ssha-po-mi rotvorcheskoy-missii-na-donbasse (11 VII 2021).

12 О. Игнатов, op.cit.

13 Забути про „миротвориів”: Україна повинна відмовитися від слова, яке шкодить нам на Донбасі, https://www.eurointegration.com.ua/rus/articles/2019/05/30/7096766/ (18 VII 2021). 
министр иностранных дел РФ С. Лавров при упоминании „предложений США по миссии ООН на востоке Украины” подчёркивал, что „Донбасс не сдастся” 14 , называл миротворцев „оккупационными силами”15. Президент РФ В. Путин несколько раз вспоминал о трагедии в Сребренице, оценивая возможные последствия возвращения контроля над границей в зоне конфликта до выполнения политической части Минских соглашений ${ }^{16}$. О нежелании обсуждать тему миротворцев свидетельствуют прямые заявления представителей МИД РФ ${ }^{17}$.

Тема миротворческой миссии ООН на Донбассе больше не фигурирует в медиа-пространстве, как и не существует на сегодняшний день официальных каналов коммуникации, по которым она могла бы обсуждаться. Совет Безопасности ООН так и не стал площадкой для предметных обсуждений, в 2018 г. прекратились переговоры в формате Сурков-Волкер. Но уже в следующем 2019 г. появился новый сюжет в обсуждении присутствия миротворцев в зоне конфликта. Опасения по поводу ввода российских миротворцев под предлогом защиты своих граждан стали выражать украинские политики. Основанием для этого была упрощенная процедура предоставления гражданства РФ жителям ОРДЛО. В условиях новой политической реальности обращают на себя внимание слова, сказанные одним из главных российских переговорщиков по Донбассу. На встрече с экспертами Института мировой экономики и международных отношений РАН в апреле 2021 г. Д. Козак заметил, что „если там будет, как говорит наш президент, устроена Сребреница, видимо, вынуждены будем встать на защиту”18. Замглавы АП РФ также не исключил курса на „замораживание” конфликта.

Исключение вопроса о миротворческой миссии из официальной повестки дня международных переговоров сместило данную тему в политическое пространство Украины, в котором она фигурирует преимущественно в контексте борьбы за власть. Различное понимание целей и задач миротворцев обнаружилось во время президентской кампании 2019 г. Хотя тема миротворческой миссии затрагивалась в программах лишь отдельных

14 Лавров о миротвориах ООН: Донбасс не сдастся, https://news.liga.net/politics/news/lavr ov-o-mirotvortsah-oon-donbass-ne-sdastsya (18 VII 2021).

15 Лавров назвал миротвориев ООН для Донбасса „оккупационными силами”, https://www. eurointegration.com.ua/rus/news/2017/10/31/7073009/ (20 VII 2021).

16 Заседание Совета по развитию гражданского общества и правам человека, 10 XII 2019, http://kremlin.ru/events/president/news/62285 (10 VIII 2021).

17 Вопрос введения в Донбасс миротворческой миссии ООН в повестке дня урегулирования внутриукраинского конфликта не стоит, https://www.gazeta.ru/army/news/2021/ 04/21/15887588.shtml (10 VIII 2021).

18 Козак: Россия встанет на защзиту своих граждан в случае войны в Донбассе, https://www. kommersant.ru/doc/4762951 (10 VIII 2021). 
кандидатов в президенты Украины. Те из них, кто декларировал необходимость введения миротворцев, как оказалось, по-разному понимали их задачи, как и сам процесс восстановления мира. Наиболее „узкий” подход содержит программа кандидата А. Вилкула: введение миротворческой миссии предусматривалось только в качестве первого шага на пути к восстановлению мира. В задачу миротворцев входило разъединение противоборствующих сторон и обеспечение режима прекращения огня. Что касается состава миротворческого контингента, то он должен был формироваться из числа дружественных и нейтральных стран (Беларусь, Казахстан, Азербайджан, Финляндия, Швеция, Австрия) ${ }^{19}$. Предвыборная программа П. Порошенко, по сути, повторяла официальную позицию Украины в данном вопросе ${ }^{20}$. „Широкий подход” был предложен кандидатом в президенты С. Тарутой, в программе которого миротворческая миссия ООН была представлена как часть мирного плана наряду с международной временной администрацией „для обеспечения социально-экономического развития региона и реинтеграции жителей Донбасса". Существенным для понимания данного подхода является уточнение, что предпосылкой реализации предложенного мирного плана должен был стать внеблоковой статус Украины ${ }^{21}$. Это и было то политическое соглашение, для обеспечения которого миротворцы должны были появиться на Донбассе. Как видно, предложенный политиком „компромисс” плохо согласовался с курсом на европейскую и евроатлантическую интеграцию Украины.

В предвыборной программе действующего президента В. Зеленского пункт о завершении войны и возвращении временно оккупированных территорий не содержал упоминаний о миротворцах ${ }^{22}$. Тем не менее, вопросы восстановления мира на Донбассе были одними из ключевых в коммуникации кандидата с электоратом. Поэтому после президентских выборов было непонятно: будет ли продолжена линия предыдущего президента в вопросах прекращения войны и миростроительства, и соответственно сохранится ли выстроенная на тот момент коммуникация миротворческой миссии.

Президент В. Зеленский неоднократно высказывался о желательности присутствия миротворцев на российско-украинской границе (без уточнения того, как они могут там появиться) (сентябрь 2019 г., открытие саммита

19 Вілкул Олександр Юрійович, https://www.cvk.gov.ua/pls/vp2019/wp005pt021f01=224pt001f01=720.html (10 VIII 2021).

20 Порошенко Петро Олексійович, https://www.cvk.gov.ua/pls/vp2019/wp005pt021f01=295pt001f01=720.html (10 VIII 2021).

21 Тарута Сергій Олексійович, https://www.cvk.gov.ua/pls/vp2019/wp005pt021f01=234pt001f01=720.html (10 VIII 2021).

22 Зеленський Володимир Олександрович, https://www.cvk.gov.ua/pls/vp2019/wp005pt021f01=233pt001f01=720.html (10 VIII 2021). 
Ялтинской стратегии YES-2019223. Подготовка к саммиту нормандской четверки (декабрь 2019 г.), как и сами результаты Парижского саммита, свидетельствовали о том, что команда нового президента пыталась достигнуть компромисса в последовательности имплементации пунктов Минских соглашений. Однако сложности в реализации данного подхода вынуждали украинских переговорщиков время от времени возвращаться к теме миротворческой миссии. Только теперь она подавалась как вынужденная альтернатива Минску-2. Впервые о миротворцах как „плане Б” достаточно ясно выразился министр иностранных дел Украины В. Пристайко ${ }^{24}$. В феврале 2020 г. он выступил в ГА ООН и указал на необходимость разместить миротворцев $\mathrm{OOH}$ на неконтролируемом участке российско-украинской границы. Задача миссии определялась необходимостью создать „коридор безопасности на украинско-российской границе” для проведения местных выборов на всей территории Украины, запланированных на осень 2020 г. Осенью 2020 г. вице-премьер А. Резников публично подтвердил, что вопрос миротворческой миссии не снят с повестки дня, а лишь отложен ${ }^{25}$. Теперь же очевидно, что он становится предметом внутриполитической борьбы между властью и оппозицией. 21 IV 2021 г. во время телемарафона в эфире телеканалов „Прямой”, „Экспрессо” и „5 канал” П. Порошенко напомнил о письмах, с которыми Украина официально обращалась в ООН в 2015 г. о введении миротворческой миссии. Политик пояснил, что тогда этот процесс был синхронизирован с подписанием Минских соглашений и предложил передать наработки своей команды в вопросе миротворческой миссии $\mathrm{OOH}$ действующей власти ${ }^{26}$. Ответа на данные предложения пока не поступало.

Таким образом, украинские и российские официальные нарративы о миротворческой миссии ООН помещены в контекст урегулирования конфликта на Донбассе, необходимости выполнения Минских соглашений и не рассматриваются в контексте нормализации двусторонних отношений Украины и РФ. Во украинском дискурсе содержательная часть

23 Що говорив Зеленський на форумі YES-2019, https://www.youtube.com/watch?v=BC-7KksPyD8\&t=43s (13 VIII 2021).

24 Пристайко: Украина хочет добавить в Минские соглачения миротворческую миссию, http://24news.com.ua/158191-ukraina-xochet-dobavit-v-minskie-soglasheniya-mirotvorche skuyu-missiyu-pristajko/ (15 VIII 2021).

25 План-Б: с какой иелью на Украине снова заговорили о введении миротворческой миссии ООН в Донбасс, https://russian.rt.com/ussr/article/785447-ukraina-donbass-mirotvorcy-oon (15 VIII 2021).

26 Украина обращзалась в ООН относительно миротвориев на Донбассе еще в 2015 году. ЕС стойко солидарен с Украиной, https://qha.com.ua/ru/novosti/ukraina-obrashhalas-k-oon-otnositelno-mirotvortsev-na-donbasse-eshhe-v-2015-godu-es-ustojchivo-solidaren-s-ukrainoj/ (15 VIII 2021). 
коммуникации миротворческой миссии является маркером, по которому можно определять варианты будущего государственного строительства и миростроительства.

\section{Кризис переговорных площадок}

Коммуникация миротворческой миссии ООН со всей очевидностью продемонстрировала кризис существующих переговорных форматов. Ни в рамках Нормандской четверки (Н-4), ни в рамках специально созданного трека Сурков-Волкер сторонам не удалось согласовать общий подход к урегулированию. Не оправдались надежды украинской стороны на превращение Совета Безопасности (СБ) $\mathrm{OOH}$ в площадку для широкой коммуникации миротворческой миссии. В 2016-2017 г. Украина имела статус непостоянного члена СБ, поэтому ее представитель имел бы возможность непосредственно принимать участие в обсуждениях. Однако подготовленный украинскими дипломатами проект резолюции не был вынесен на рассмотрение ввиду существенных расхождений с российским документом. Чтобы попытаться сблизить позиции сторон, был создан новый канал коммуникации. Ключевыми фигурами в нем стали спецпредставитель Госдепартамента США по Украине К. Волкер и помощник президента РФ В. Сурков. Очевидно, что РФ воспринимала американского дипломата как представителя стороны, которая имеет возможность повлиять на Украину в плане выполнения нею обязательств в рамках Минских соглашений. Видимо не случайно и первая встреча представителей США и РФ состоялась именно в Минске - столице Минского переговорного процесса. Это был важный символический акт, поскольку США не являются участником данного процесса. Кроме того, обсуждение миротворческой миссии переходило на новый уровень, и было не понятно, сможет ли коммуникация Сурков-Волкер дополнить переговоры в Норманнском формате.

Первая встреча спецпредставителя Госдепартамента США и помощника президента РФ (21 VIII 2017 г.) имела подготовительный характер, проходила на фоне принятия в США решения о поставках летального оружия Украине. По ее итогам В. Сурков заявил о том, что обе стороны предложили свежие идеи и новаторские подходы к реализации Минских соглашений ${ }^{27}$. На встречу в Белград (13 XI 2017 г.) американский дипломат подготовил „29 абзацев” поправок к российскому проекту резолюции ${ }^{28}$. Очевидно,

27 Сурков назвал встречу с Волкером серьезной и непредвзятой, https://lenta.ru/news/2017/ 08/21/survol (17 VIII 2021).

28 Россия снова не договорилась с США о миротвориах в Донбассе. Почему?, https://www. bbc.com/russian/features-41972588 (17 VIII 2021). 
он, по сути, переписал первоначальный документ, поскольку только три из них оказались приемлемыми для российской стороны. Хотя миротворцы сами по себе не гарантируют завершения конфликта, но и попытка усилить реализацию политических пунктов Минских соглашений присутствием в них ООН, оказалась сложной для поисков компромисса. 18 I 2018 г. Верховная Рада Украины приняла (во втором чтении) Закон об особенностях государственной политики по обеспечению государственного суверенитета Украины над временно оккупированными территориями в Донецкой и Луганской областях, в котором были урегулированы правовые основы использования ВСУ на востоке, а Россия названа страной-агрессором ${ }^{29}$. Накануне встречи в Дубае стороны не выражали оптимизма ${ }^{30}$. Как стало известно позже, этот проект закона стал главным камнем преткновения на переговорах. В. Сурков заявил, что законом о реинтеграции Украина „пытается легализовать противоправные действия на Донбассе”з1. Так данный переговорный формат, ставший основной площадкой для обсуждения участия ООН в реализации Минских соглашений, оказался фактически замороженным. На последней встрече, состоявшейся 28 I 2018 г. в Дубае, В. Сурков предварительно одобрил идею К. Волкера о поэтапном развертывании миротворческой миссии ООН. Но предложенный американским дипломатом план синхронизации развертывания с поэтапным выполнением политических пунктов Минска-2 не устроил российскую сторону. Дальнейшие попытки поддерживать канал коммуникации лишь показали, что стороны не готовы к конструктивным переговорам ${ }^{32}$.

Поэтому обсуждение миротворческой миссии продолжилось в рамках Нормандского формата. Эта тема стала главной на переговорах министров иностранных дел Н-4 11 VIII 2018 г. в Берлине (после перерыва в 16 месяцев) и рассматривалась как „пространство для компромисса”, в котором Украина и РФ могли бы согласовать интересы и позиции. Артикулированная министром иностранных дел ФРН Г. Маасом позиция состояла в том, что миротворцы могли бы оживить Минский процесс, создать для него „новые рамочные условия" 33 . После завершения переговоров участники огласили свои разногласия по ключевым вопросам мирного урегулирования.

29 Проект Закону про особливості державної політики із забезпечення державного суверенітету Украйни над тимчасово окупованими територіями в Донецькій та Луганській областях, http://w1.c1.rada.gov.ua/pls/zweb2/webproc4_1?pf3511=62638 (11 VIII 2021).

30 Курт Волкер: Конфликт на Донбассе можно остановить за год, https://www.bbc.com/ ukrainian/features-russian-42815044 (3 VIII 2021).

31 РосСМИ: Сурков назвал предложения США по миссии ООН на Донбассе „реализуемьмu”, https://www.pravda.com.ua/rus/news/2018/01/27/7169720/ (27 VIII 2021).

32 О. Игнатов, op.cit.

33 Нормандская четверка не достигла компромисса по вопросу о миссии ОOH, https:// www.dw.com/ru/a-44167765 (27 VIII 2021). 
Глубина разногласий стала очевидной, когда Германия, Франция и Украина назвали главной темой переговоров вопрос о миссии ООН, а РФ акцентировала внимание на несоблюдении договоренностей, достигнутых на предыдущих саммитах Н-4 в 2015-2016 гг. Министр иностранных дел РФ С. Лавров потребовал завершить отвод войск в станице Луганской и юридически закрепить „формулу Штайнмайера”. Последнее касалось изменений украинского законодательства об особом статусе таким образом, чтобы ОРДЛО смогли получить автономию на временной основе в день проведения местных выборов, а на постоянной - после признания выборов состоявшимися БДИПЧ ОБСЕ ${ }^{34}$.

Н-4 играет роль одновременно гаранта и верификатора выполнения Минска-2 и связанных с ним договоренностей. Все ключевые решения по имплементации „Комплекса мер” принимаются на ее уровне. Украина хотела бы вести переговоры о миротворцах в Нормандском формате, где есть РФ и нет ОРДЛО. В то же время Россия хотела бы, чтобы проблема обсуждалась в ТКГ, где она позиционирует себя как медиатор, и есть представители самопровозглашенных республик. Российские официальные лица неоднократно выражали обеспокоенность попытками представить Нормандский формат как „единственную реальную основу для урегулирования на Украине”35. Об отношении российских переговорщиков к переговорам в Нормандском формате свидетельствует высказанное весной 2021 г. предложение сделать их публичными. В данном случае основная претензия адресовалась украинской стороне, которая, по мнению Д. Козака, пытается за счет выгодного ей освещения переговоров доминировать в информационном пространстве и „дезинформировать своих граждан”з

Завершая обзор переговорных площадок, следует отметить, что в ТКГ миротворческая миссия ООН не обсуждалась. Участники украинской переговорной группы последовательно выступали против обсуждения данного вопроса с представителями ОРДЛО. В целом потенциал ТКГ, особенно последнее время, особого оптимизма не вызывает. Данное обстоятельство признается и представителями ОБСЕ, которые выступают посредниками на этой переговорной площадке. Так, в опубликованном сообщении по случаю завершения работы П. Морреля и Т. Фриша Спецпредставитель ОБСЕ в Украине Х. Грау отметила, что „в политической рабочей подгруппе уже достаточно давно не удается найти конструктивный подход и выполнить

34 О. Игнатов, op.cit.

35 Москва повышает ставки. Что означает выступление представителей „ЛНР/ДНР” в $\mathrm{OOH}$, https://strana.ua/news/304355-sovbez-oon-s-dnr-i-lnr-zajavlenija-po-ukraine-vide o-zasedanija-2122020.html (6 VII 2021).

36 Дмитрий Козак и Тайная комната, https://www.kommersant.ru/doc/4763218 (6 VII 2021). 
поручение ТКГ разработать план действий в полном соответствии с Минскими соглашениями. Хотела бы отметить, что в данном случае процедурные вопросы доминируют над обсуждением конкретных мер" ${ }^{37}$.

Таким образом, в коммуникации миротворческой миссии не удалось использовать готовые переговорные площадки для того, чтобы переместить проблему в пространство достижения компромисса. Не увенчалась успехом попытка создать новый канал коммуникации, включающий США. Совбез также не стал площадкой для широкой международной коммуникации, продемонстрировав ограниченные возможности ООН в урегулировании конфликта на востоке Украины.

\section{Общественные настроения: за и против миротворцев ООН}

Общественные настроения и их динамика являются одним из показателей уровня и качества коммуникации власти с обществом. В вопросах урегулирования конфликта и миростроительства они приобретают критически важное значение. Коммуникация миротворческой миссии ООН показывает, что ее самым слабым звеном было взаимодействие власти и общества, а в содержательном плане - излишняя политизация и дефицит гуманитарного аспекта. Официальную украинскую власть интересовал преимущественно вопрос формирования социальной базы будущей политики урегулирования конфликта на Донбассе. Было очевидно, что Минские соглашения невозможно выполнить без ущерба для той Украины, которая возникла в результате Евромайдана. Попытки договориться об изменениях данных соглашений создавали лишь политико-дипломатические тупики и приводили к лишней напряженности в зоне конфликта. Соглашения о прекращении огня и отводе военной техники никогда и не соблюдались. В тоже время наличие Минских соглашений сдерживало стороны от эскалации конфликта, который после 2015 г. характеризовался низкой интенсивностью. Поэтому присутствие миротворцев в зоне конфликта могло рассматриваться как инструмент, способный усилить достигнутые в Минске договоренности. Насколько такой подход воспринимался в украинском обществе?

Если фокусироваться исключительно на сценарии развертывания миротворческой миссии ООН, то социологические опросы 2015-2019 гг.

37 Сообщение для печати Специального представителя Действующего председателя ОБСЕ в Украине Хайди Грау после очередной встречи ТКГ 23 июня 2021 г., https://www. osce.org/ru/chairmanship/490802 (7 VII 2021). 
показывают устойчивую положительную динамику. Вероятно одним из первых социологических исследований в регионе, непосредственно примыкавшем к зоне конфликта, стал опрос жителей Луганской области в марте-апреле 2015 г. Он был проведен Фондом „Демократические инициативы имени Илька Кучерива" совместно с компанией Ukrainian Sociology Service в рамках проекта „Реинтеграция Донбасса в Украину через коммуникацию”. Само название проекта указывало на значимость каналов взаимодействия с населением в зоне конфликта. Оказалось, что идея миротворческой миссии не имеет поддержки среди опрошенных жителей Северодонецка и Старобельска. Только $22 \%$ респондентов высказались за введение международных миротворческих сил. При этом большая часть сторонников миротворцев не смогли сказать точно, на какие территории мог бы распространяться мандат миротворческой миссии. Большая часть опрошенных не смогла также ответить на вопрос, из каких стран должен формироваться миротворческий контингент. При этом только $2 \%$ поддержали идею участия России в миротворческой миссии ${ }^{38}$.

Ситуация выглядела кардинально иной в рамках общенациональных опросов, общим недостатком которых было отсутствие данных по Крыму и неподконтрольной части Донецкой и Луганской областей. По данным общенациональных социологических опросов (без Крыма и ОРДЛО), проведенных в 2016-2019 гг., уровень поддержки миротворческой миссии составил: 2016 г. - 58\%, 2017 г. - 60,2\%, май 2018 г. - 60,6\%, декабрь 2018 г. - 54,4\%, 2019 - 58,9\% Региональный срез опроса показал, что на востоке Украины среди сторонников миротворческой миссии оказалось $47 \%$ опрошенных, на западе - 70\%, на юге - 64\% ${ }^{39}$. В 2018 г. опросы, включающие вопрос о миротворцах, проводились несколько раз разными социологическими службами. По данным исследования Центра Разумкова, среди граждан Украины (кроме Крыма и ОРДЛО) большинство опрошенных (42\%) считали, что не следует согласовывать введение миротворцев $\mathrm{OOH}$ с самопровозглашенными республиками, а $34 \%$ - поддержали такую идею. Кроме того, $43 \%$ респондентов высказались за то, чтобы силы ООН взяли под контроль всю оккупированную территорию, включительно с участком украинско-российской границы, а $15 \%$ - согласились с российской позицией - миротворцы должны обеспечивать только охрану СММ ОБСЕ на

38 Луганщина: потребности, страхи, оиенки ситуации и надежды на будущее, https://dif. org.ua/article/luganshchinapotrebnosti-strakhi-otsenki-situatsii-i-nadezhdy-na-budushchee (6 VII 2021).

39 Шляхи досягнення миру на Донбасі: суспільні настрої, очікування, перестороги - загальнонаціональне опитування, https://dif.org.ua/article/shlyakhi-dosyagnennya-miru-na-donbasi-suspilni-nastroi-ochikuvannya-perestorogi-zagalnonatsionalne-opituvannya (28 VII 2021). 
линии соприкосновения. Имела место и региональная специфика: на западе и в центре страны большинство граждан поддерживали идею контроля силами ООН всей оккупированной территории, включая неконтролируемый Украиной участок границы, а на юге и востоке мнения респондентов оказались неоднозначны ${ }^{40}$.

В результате коммуникации за несколько лет сформировалась общественная поддержка для включения миротворческой миссии в процессы урегулирования. Но она не включала людей, с которыми бы пришлось взаимодействовать миротворцам ООН в случае развертывания миссии. С другой стороны, вследствие исключения из коммуникации жителей ОРДЛО „власти” самопровозглашенных республик ситуация могут говорить от имени всего населения и беспрепятственно повторять российские нарративы о миротворцах $\mathrm{OOH}^{41}$. Свои выгоды получила РФ: изоляция ОРДЛО создала удобный повод к началу паспортизации их жителей и трактования этой политики как „гуманитарного жеста”, а также обвинений Украины в невыполнении Минских соглашений. Весной 2021 г. пресс-центр МВД РФ сообщил, что гражданство РФ получили более 527 тыс. лиц, постоянно проживающих на территории ОРДЛО ${ }^{42}$. Секретарь СНБО Украины А. Данилов называет цифру 630 тыс. паспортов ${ }^{43}$. В Украине только некоторые официальные лица признают наличие гуманитарной составляющей в паспортизации жителей ОРДЛО. Уполномоченная ВР Украины по правам человека Л. Денисова считает, что жители Донбасса принимают российское гражданство, „чтобы была возможность получить какие-то дополнительные выплаты, лечиться... Еще это касается тех людей, которые работают учителями, врачами - если они не получают такие паспорта, то они лишаются вообще работы. Поэтому люди, чтобы выжить, берут эти паспорта"44.

Излишнюю политизацию и дефицит внимания к гуманитарным аспектам коммуникации с местным населением демонстрирует пример восстановления в конце июня 2018 г. контроля украинских военных над поселком

40 Российско-украинский конфликт: перспективы и параметры миротворческой миссии ООН на Донбассе: материаль для трехсторонней экспертной встречи 14-17 августа 2018 2., https://razumkov.org.ua/uploads/article/2018_Russian-Ukrainian_Conflict_ru_ en.pdf (28 VII 2021).

41 Пушилин объяснил, почему в Донбассе нет миротвориев, https://ura.news/news/1052483448 (29 VII 2021).

42 В Донбассе может не остаться украинских граждан, https:/www.ng.ru/cis/2021-07-06/ 5_8191_ukraine.html (28 VII 2021).

43 „Было бы странно проводить выборы”. Данилов назвал количество паспортов РФ на Донбассе, https://news.liga.net/politics/news/bylo-by-stranno-provodit-vybory-danilov-naz val-kolichestvo-pasportov-rf-na-donbasse (30 VII 2021).

44 В Донбассе может не остаться украинских граждан, https://www.ng.ru/cis/2021-07-06/ 5_8191_ukraine.html (30 VII 2021). 
Золотое-4. Местные жители пожаловались наблюдателям СММ ОБСЕ, „что они не чувствуют себя в безопасности, когда военные находятся в центре поселка" 45 . Никто не обратил тогда внимание на их нужды. Глава военно-гражданской администрации К. Ильченко в своих комментариях делал акцент исключительно на уменьшении серой зоны: „В любом случае поселок находится на переднем крае, и с учетом дальности полета мины он будет оставаться в зоне поражения. Но серая зона уменьшилась - это факт. Золотое-4 окончательно под украинским влиянием"46.

В октябре 2019 г. украинским военным пришлось уйти из поселка, поскольку разведение сил в районе населенных пунктов Золотого и Петровское было одним из предварительных условий саммита в Нормандском формате. Президенту В. Зеленскому пришлось лично прибыть на место и вести переговоры с активистами „Национального корпуса”, решившими устроить собственный блокпост в Золотое-4.

Внимание к гуманитарному аспекту развертывания миротворческих миссий касается не только ситуации на Донбассе, где большая часть местного населения не может определиться в данном вопросе. Защита местного населения является одним из оснований для организации миротворческих операций. Отсутствие поддержки местного население ставит под сомнение легитимность вмешательства ООН в конфликт, и усугубляет проблему безопасности для самих миротворцев. Как раз в период активного обсуждения миротворческой миссии на Донбассе на базу ООН, расположенную в восточной части Демократической Республики Конго, было осуществлено нападение. В результате погибло 15 миротворцев. Наблюдаемое в последнее время увеличение количества потерь среди миротворцев, вынудило еще раз пересмотреть концепцию миротворческой деятельности. В подготовленном бывшим командующим силами ООН Карлосом Альберто Крузом докладе „О повышении безопасности миротворцев ООН” среди прочего было рекомендовано „изменить образ мышления персонала и подготовить его к демонстрации военной мощи”. Данная рекомендация вызвала противоречивые оценки со стороны экспертов, указывавших на необходимость поиска политических решений для поддержки миротворческих миссий, взаимодействия с местным населением или защиту гражданских лиц ${ }^{47}$.

45 О. Игнатов, op.cit.

46 Украинские военные полностью освободили поселок Золотое-4, но он остается в зоне поражения - местные власти, https:/gordonua.com/news/war/ukrainskie-voennye-polnostyu-osvobodili-poselok-zolotoe-4-no-on-ostaetsya-v-zone-porazheniya-mestnye-vlasti-253747.html (30 VII 2021).

47 Strategist: В ООН необходимо провести срочные ребормы, https://regnum.ru/news/polit/ 2375955.html (5 VIII 2021). 
Российская сторона, актуализируя эту уязвимость в реализации первоначальных предложений Украины, неоднократно предупреждала, что „в Донбассе не будет никаких миротворцев без согласия Луганска и Донецка”. Председатель комиссии Совета Федерации по информационной политике А. Пушков в Twitter так прокомментировал переговоры вокруг миротворческой миссии: „Порошенко надо обсуждать ввод миротворцев не с Меркель или Волкером, а с Донецком и Луганском. Без их согласия не будет там никаких миротворцев" 48 .

Описанную выше ситуацию можно определить как проблему „начальных условий”. Речь идет о том, что для развертывания миротворческой миссии должны быть созданы определенные условия: соблюдение сторонами режима прекращения огня, концентрация вооруженных сил и тяжелой техники в установленных местах и т.д. Иначе не исключается ситуация, когда миротворцы ООН окажутся втянутыми в вооружённый конфликт. С этой точки зрения увеличение контактов через линию разграничения на Донбассе способствовало бы коммуникации миротворческой миссии.

Оценивая перспективы миротворческой миссии в зоне конфликта в разрезе общественных настроений, следует иметь в виду отсутствие ясного понимания того, как относиться к жителям ОРДЛО. Проблемой для выстраивания эффективной коммуникации в данном случае остается четкое определение правовых основ для амнистии разных категорий населения неконтролируемых территорий, что способно создать стимулы для поддержки этими людьми политики официального Киева в вопросах восстановления мира и миростроительства.

Гражданское общество в Украине играет заметную роль в процессах урегулирования конфликта, в том числе используя свой протестный потенциал. В октябре 2019 г. в Киеве была организована акция протестов против „формулы Штайнмаера”. Участники акции говорили об утрате чувства безопасности, о неуверенности в завтрашнем дне, о дискомфорте от тайной, по их мнению, подготовки решений, способных повлиять на их жизнь ${ }^{49}$. Весной 2020 г. разразился скандал, когда стали известны содержания договоренностей между А. Ермаком и Д. Козаком об создании дополнительной переговорной площадки - консультативном совете. Предполагалось, что представители Украины и ОРДЛО попытаются использовать данный формат для переговоров по политическим и юридическим вопросам. После того, как в адрес президента В. Зеленского и главы его офиса прозвучали обвинения в капитуляции и измене, А. Ермак отозвал свою подпись под

48 Миротвориь в Донбассе: Украина боится „сговора Берлина и Москвы”, https://regnum. ru/news/polit/2398997.html (5 VIII 2021).

49 Украина: тысячи противников формулы Штайнмаера собрались под окнами Зеленского, https://www.bbc.com/russian/news-49953210 (5 VIII 2021). 
документом. Как видно, реальные политические процессы, происходящие в Украине и на неподконтрольных территориях, достаточно далеко разошлись в разных направлениях, чтобы обеспечить гарантии мира, предусмотренные Минскими соглашениями.

\section{Выводы}

Выбор и продвижение различных сценариев урегулирования конфликта на востоке Украины предполагает взаимодействие субъектов принятия решений, заинтересованных лиц, групп влияния, гражданского общества, СМИ и др. Соответственно для обмена мнениями, ведения переговоров, совместного поиска решения проблемы или продолжения борьбы используются разные каналы коммуникации, в том числе неформальные.

Тема миротворческой миссии ООН на Донбассе в 2015-2019 гг. оказалась в центре выстроенной системы коммуникации, включавшей целый спектр каналов - от телефонных звонков президентов Украины и РФ до экспертных обсуждений и социологических опросов по выявлению общественных настроений. Преимуществами этой системы коммуникации стало вовлечение широкого круга заинтересованных лиц и групп влияния, происходившее посредством создания новый форматов переговоров (трек Сурков-Волкер) и использование уже проверенных площадок (СБ и ГА $\mathrm{OOH}$, Нормандская четверка, Мюнхенская конференция по безопасности и др). Основные участники коммуникации уделяли пристальное внимание информационному сопровождению переговоров. Однако ООН, за счет участия которой предполагалось усилить Минский процесс, так и не стала брокером урегулирования конфликта на востоке Украины.

Дискуссии вокруг организации миротворческой миссии показали несовпадающие интересы участников переговоров и их стремление контролировать процессы миростроительства. Коммуникация показала расстановку и соотношение сил в конфликте, выявила резервы, которые участники могут использовать для усиления собственных позиций и ослабления позиций другой стороны в будущем. Нежелание сторон договариваться, использование разных каналов коммуникации для пропаганды собственных подходов к урегулированию привели к кризу переговорных форматов и исключению вопроса о миротворческой миссии ООН с повестки дня международных переговоров. Преимущественная сосредоточенность на решении политических вопросов, излишняя политизация миротворческой миссии и невнимание к гуманитарным проблемам жителей ОРДЛО не способствовали переговорному процессу. Такой дисбаланс стал следствием потери каналов коммуникации между официальным Киевом и населением некон- 
тролируемых территорий. Но именно лояльное отношение местного населения к миротворцам ООН могло быть решающим аргументом в пользу принятия решения о миротворческой операции. Возврат к обсуждению в будущем данного вопроса сегодня кажется маловероятным ввиду новой политической реальности, возникшей в ОРДЛО после введения упрощенной процедуры получения гражданства РФ. И любые попытки снова ввести в дискурс урегулирования слово „миротворцы” могут закончиться развертыванием российского миротворческого контингента и „замораживанием" конфликта на Донбассе. В этой связи сегодняшней украинской власти и оппозиции следует быть предельно осторожными в использовании темы миротворцев в политической борьбе.

\section{Abstract}

Iryna Bohinska

\section{Communication of the peacekeeping mission in eastern Ukraine}

The article examines the conflict over the idea UN peacekeeping mission in eastern Ukraine between Ukraine and Russian Federation. The analysis of the conflict is based on a critical approach to the official narratives which is containing references to the UN peacekeepers in 2015-2021. It was established that the first time the idea UN peacekeeping mission appeared in the Ukrainian political discourse immediately after the signing of the second part of the Minsk agreements (Minsk-2). It found itself in the center of international discourse after Russian President V. Putin initiated the submission of the draft resolution to the UN Security Council. The Russian approach to the peacekeeping mission was formulated in a strict connection with the implementation of the Minsk agreements and did not allow their interpretation. Generally, the Russians' Federation („defensive concept”) and Ukraines' („broad mandate”) approaches are developing and adapting the concept of modern peacekeeping to the interests of the conflict parties. Russian-Ukrainian narratives are the basis for an in-depth understanding of the conflict nature and possible ways to resolving. The using of propaganda tools to promote multidirectional approaches to UN peacekeepers has taken the conflict to a higher level.

The analysis of the communications the peacekeeping mission includes negotiation formats which the issue was discussed. Such negotiating platforms were the Normandy format, the Munich Security Conference, the UN General Assembly, the Surkov-Volker track etc. The UN Security Council did not become an additional channel of communication, because it was not possible to coordinate and 
bring together the Ukraine's position and the Russians' Federation ones. Attempts to agree on a peacekeeping mission within the framework of the implementation of the Minsk agreements created a negotiation deadlock and the exclusion of this item from the agenda of international negotiations.

The article focuses on the factor of formation the public support for the scenario of conflict settlement which is based on the UN. The issue was investigated on opinion polls and an arbitrary selection of plots, which are formed the evidence base for assessing the influence the civil society in decision-making in Ukraine. At the same time, it shows the humanitarian aspects that would have the potential to influence the conflict settlement processes in Donbass.

Keywords: peacekeeping mission, communication, Ukraine, Russian Federation, UN, Minsk agreements

\section{References}

Arsen Avakov: U menya est' plan. Uslovno, vzyat' snachala otdel'no Gorlovku, https://www.pravda.com.ua/articles/2018/04/16/7177768/.

«Bylo by stranno provodit' vybory». Danilov nazval kolichestvo pasportov RF na Donbasse, https://news.liga.net/politics/news/bylo-by-stranno-provodit-vybory-danilov-nazval-kolichestvo-pasportov-rf-na-donbasse.

Croatian peacekeeping model best for Donbas - Ukraine's ministry for occupied areas, https://www.unian.info/politics/10309443-croatian-peacekeeping-modelbest-for-donbas-ukraine-s-ministry-for-occupied-areas.htm.

Dmitrii Kozak i Tainaya komnata, https://www.kommersant.ru/doc/4763218.

Donbass priobshchayut $k$ Ob"edinennym Natsiyam. Vladimir Putin predlozhil vvesti v region mirotvortsev OON, https://www.kommersant.ru/doc/3403004. Ignatov, O., Ne rvat' i ne vypolnyat'. Est' li shansy u Minska-2 posle chetyrekh let peregovorov, https://carnegie.ru/commentary/78336.

Klimkin: Rosiya proponuє «total'no feikovu misiyu» OON na Donbasi, https:// www.ukrinform.ua/rubric-polytics/2478639-klimkin-rosia-proponue-totalno-fejkovu-misiu-oon-na-donbasi.html.

Kozak: Rossiya vstanet na zashchitu svoikh grazhdan v sluchae voiny v Donbasse, https://www.kommersant.ru/doc/4762951.

Kurt Volker: Konflikt na Donbasse mozhno ostanovit' za god, https://www.bbc. com/ukrainian/features-russian-42815044.

Lavrov nazval mirotvortsev OON dlya Donbassa "okkupatsionnymi silami», https:/www.eurointegration.com.ua/rus/news/2017/10/31/7073009/. 
Lavrov o mirotvortsakh OON: Donbass ne sdastsya, https://news.liga.net/politics/ news/lavrov-o-mirotvortsah-oon-donbass-ne-sdastsya.

Luganshchina: potrebnosti, strakhi, otsenki situatsii i nadezhdy na budushchee, https://dif.org.ua/article/luganshchinapotrebnosti-strakhi-otsenki-situatsii-i-nadezhdy-na-budushchee.

Mirotvortsy v Donbasse: Ukraina boitsya «sgovora Berlina i Moskvy», https://regnum.ru/news/polit/2398997.html.

Moskva povyshaet stavki. Chto oznachaet vystuplenie predstavitelei «LNR/DNR» $v$ OON, https://strana.ua/news/304355-sovbez-oon-s-dnr-i-lnr-zajavlenija-po-ukraine-video-zasedanija-2122020.html.

Nebenzya: Kiev mussiruet temu mirotvorcheskoi missii v Donbasse dlya podryva «Minska-2», https://tass.ru/politika/4526363?utm_source=twitter.com\&utm_ medium=social\&utm_campaign=smm_social_share.

Normandskaya chetverka ne dostigla kompromissa po voprosu o missii OON, https://www.dw.com/ru/a-44167765.

Plan-B: s kakoi tsel'yu na Ukraine snova zagovorili o vvedenii mirotvorcheskoi missii OON v Donbass, https://russian.rt.com/ussr/article/785447-ukraina-donbass-mirotvorcy-oon.

Povnii tekst dokumentiv, ukhvalenikh na peregovorakh $v$ Mins'ku, https://tyzhden. ua/Politics/129751.

Poroshenko Petro Oleksiiovich, https://www.cvk.gov.ua/pls/vp2019/wp005pt021$\mathrm{f} 01=295 \mathrm{pt} 001 \mathrm{f} 01=720 . \mathrm{html}$.

Poroshenko: Mirotvortsy OON ne dolzhny byt' eskort-servisom vdol' linii razgranicheniya, https://gordonua.com/news/war/poroshenko-mirotvorcy-oon-ne-dolzhny-byt-eskort-servisom-vdol-linii-razgranicheniya-232349.html.

Pristaiko: Ukraina khochet dobavit' $v$ Minskie soglasheniya mirotvorcheskuyu missiyu, http://24news.com.ua/158191-ukraina-xochet-dobavit-v-minskie-soglasheniya-mirotvorcheskuyu-missiyu-pristajko/.

Proekt Zakonu pro osoblivosti derzhavnoï politiki iz zabezpechennya derzhavnogo suverenitetu Ukraïni nad timchasovo okupovanimi teritoriyami v Donets'kii ta Lugans'kii oblastyakh, http://w1.c1.rada.gov.ua/pls/zweb2/webproc4_1?pf3511=62638.

Pushilin ob"yasnil, pochemu v Donbasse net mirotvortsev, https://ura.news/news/ 1052483448.

Rossiisko-ukrainskii konflikt: perspektivy i parametry mirotvorcheskoi missii OON na Donbasse: materialy dlya trekhstoronnei ekspertnoi vstrechi 14-17 avgusta 2018 g., https://razumkov.org.ua/uploads/article/2018_Russian-Ukrainian_ Conflict_ru_en.pdf.

Rossiya snova ne dogovorilas's SShA o mirotvortsakh v Donbasse. Pochemu? https://www.bbc.com/russian/features-41972588. 
RosSMI: Surkov nazval predlozheniya SShA po missii OON na Donbasse «realizuemymi», https://www.pravda.com.ua/rus/news/2018/01/27/7169720/.

Shlyakhi dosyagnennya miru na Donbasi: suspilni nastroï, ochikuvannya, perestorogi-zagal'nonatsional'ne opituvannya, https://dif.org.ua/article/shlyakhi-dosyagnennya-miru-na-donbasi-suspilni-nastroi-ochikuvannya-perestorogi-zagalnonatsionalne-opituvannya.

Shcho govoriv Zelens'kii na forumi YES-2019, https://www.youtube.com/watch?v=BC-7KksPyD8\&t=43s.

Soobshchenie dlya pechati Spetsial'nogo predstavitelya Deistvuyushchego predsedatelya OBSE v Ukraine Khaidi Grau posle ocherednoi vstrechi TKG 23 iyunya 2021 g., https://www.osce.org/ru/chairmanship/490802.

Strategist: V OON neobkhodimo provesti srochnye reformy, https://regnum.ru/ news/polit/2375955.html.

Surkov nazval vstrechu s Volkerom ser'eznoi i nepredvzyatoi, https://lenta.ru/news/ 2017/08/21/survol.

Tak ne poidet. Lavrov zablokiroval idei SShA po mirotvorcheskoi missii na Donbasse, https:/vesti.lv/statja/v-mire/2018/06/12/tak-ne-poydet-lavrov-zabrakoval-ideyu-ssha-po-mirotvorcheskoy-missii-na-donbasse.

Taruta Sergii Oleksiiovich, https://www.cvk.gov.ua/pls/vp2019/wp005pt021f01=234pt001f01=720.html.

Ukaz Prezidenta Ukraïni „Pro rishennya Radi natsional'noï bezpeki i oboroni Ukraïni vid 18 lyutogo 2015 roku „Pro zvernennya do Organizatsiï Ob'€dnanikh Natsii ta Evropeis'kogo Soyuzu stosovno rozgortannya na teritoriï Ukraïni mizhnarodnoï operatsiï z pidtrimannya miru ta bezpeki” №116 vid 2 bereznya 2015 r., https://www.president.gov.ua/documents/1162015-18568.

Ukraina obrashchalas' $v$ OON otnositel'no mirotvortsev na Donbasse eshche v 2015 godu. ES stoiko solidaren s Ukrainoi, https://qha.com.ua/ru/novosti/ukraina-obrashhalas-k-oon-otnositelno-mirotvortsev-na-donbasse-eshhe-v-2015-godu-es-ustojchivo-solidaren-s-ukrainoj/.

Ukraina: tysyachi protivnikov formuly Shtainmaera sobralis' pod oknami Zelenskogo, https://www.bbc.com/russian/news-49953210.

Ukrainskie voennye polnost'yu osvobodili poselok Zolotoe-4, no on ostaetsya v zone porazheniya - mestnye vlasti, https://gordonua.com/news/war/ukrainskie-voennye-polnostyu-osvobodili-poselok-zolotoe-4-no-on-ostaetsya-v-zone-porazheniya-mestnye-vlasti-253747.html.

V Donbasse mozhet ne ostat'sya ukrainskikh grazhdan, https://www.ng.ru/cis/ 2021-07-06/5_8191_ukraine.html.

Vilkul Oleksandr Yuriiovich, https://www.cvk.gov.ua/pls/vp2019/wp005pt021f$01=224$ pt001f01 $=720 . h t m l$. 
Vopros vvedeniya $v$ Donbass mirotvorcheskoi missii OON $v$ povestke dnya uregulirovaniya vnutriukrainskogo konflikta ne stoit, https://www.gazeta.ru/army/ news/2021/04/21/15887588.shtml.

Zabuti pro «mirotvortsiv»: Ukraïna povinna vidmovitisya vid slova, yake shkodit" nam na Donbasi, https://www.eurointegration.com.ua/rus/articles/2019/05/ 30/7096766/.

Zasedanie Soveta po razvitiyu grazhdanskogo obshchestva i pravam cheloveka, 10 dekabrya $2019 \mathrm{~g}$., http://kremlin.ru/events/president/news/62285.

Zakharova: prizyvami $k$ vvodu mirotvortsev v Donbass Kiev pytaetsya uklonit'sya ot «Minska-2», https://tass.ru/politika/4503828.

Zelens'kii Volodimir Oleksandrovich, https://www.cvk.gov.ua/pls/vp2019/wp005pt021f01=233pt001f01=720.html.

Iryna Boginska - dr historii, docent w Katedrze Stosunków Międzynarodowych i Polityki Zagranicznej Narodowego Uniwersytetu Donieckiego im. W. Stusa.

ORCID: 0000-0002-0038-7765 